\title{
AVALIAÇÃO DA EFICÁCIA DE PROGRAMAS DE ROTULAGEM AMBIENTAL UMA APLICAÇÃO NO SEGMENTO DE
ELETRODOMÉSTICOS DA LINHA BRANCA
}

\section{Carla Arcoverde de Aguiar Neves, Dra. (IFSC)}

Dentro de uma realidade diferenciada de sociedade, na qual se buscam práticas e ações menos impactantes ao meio ambiente, crê-se na validade e na significância dos estudos sobre os meios que viabilizam a busca por este equilíbrio entre as esferas social, econômica e ambiental.

Sobre isso, percebeu-se falhas de eficácia e dificuldade com relação ao cumprimento das funções básicas de comunicação dos rótulos ambientais para os consumidores. Estes instrumentos apresentam deficiências que comprometem sua credibilidade, relevância, precisão, aceitação e compreensão.

O trabalho aqui apresentado se propõe a investigar este importante instrumento que é a rotulagem ambiental. Sendo assim, esta pesquisa procura identificar fatores de eficácia dos programas de rotulagem ambiental a partir da percepção do consumidor, para posterior aplicação em análise comparativa entre selos ambientais destinados ao segmento de eletrodomésticos da Linha Branca.

Para isso, estabeleceu-se um paralelo entre o que a norma NBR ISO 14020:2002 indica no que tange aos preceitos de confiabilidade, valor das informações, precisão, aceitação e compreensão; e o que a literatura acerca de rotulagem ambiental orienta para $o$ atendimento de tais preceitos.

Os fatores identificados foram validados perante especialistas da área de Gestão Am- biental e, principalmente, junto a uma parcela de possíveis consumidores na região da Grande Florianópolis (SC), buscando-se diagnosticar quais fatores eram definidos como os mais significativos.

Dois modelos estruturais foram testados também com o intuito de definir correlações entre os cinco construtos determinados e seus itens. Para tanto, tem-se os seguintes resultados de correlação:

Os resultados demonstraram uma necessidade emergente de aplicação de alegações ambientais verídicas e objetivas, porém com apontamento de informações adicionais sobre o real impacto ambiental dos produtos rotulados, o que exige o uso de outros substratos como mídias alternativas ao próprio rótulo. Além disso, a intervenção do Estado em um contexto nacional, não foi priorizada, possivelmente em função de uma realidade de falta de confiança nestas instituições e também o vínculo com marcas tidas como sustentáveis, deve permitir o alcance da verdade sobre as colocações realizadas, evitando-se alegações infundadas.

Por fim, fez-se a comparação entre os selos de eletrodomésticos da Linha Branca, a qual demonstrou fragilidade em todos os analisados, mas aquele que se evidenciou como mais distante das prioridades definidas pelos consumidores foi o ABNT Qualidade Ambiental. 
Figura 1: Representação do Modelo Estrutural 01 ajustado

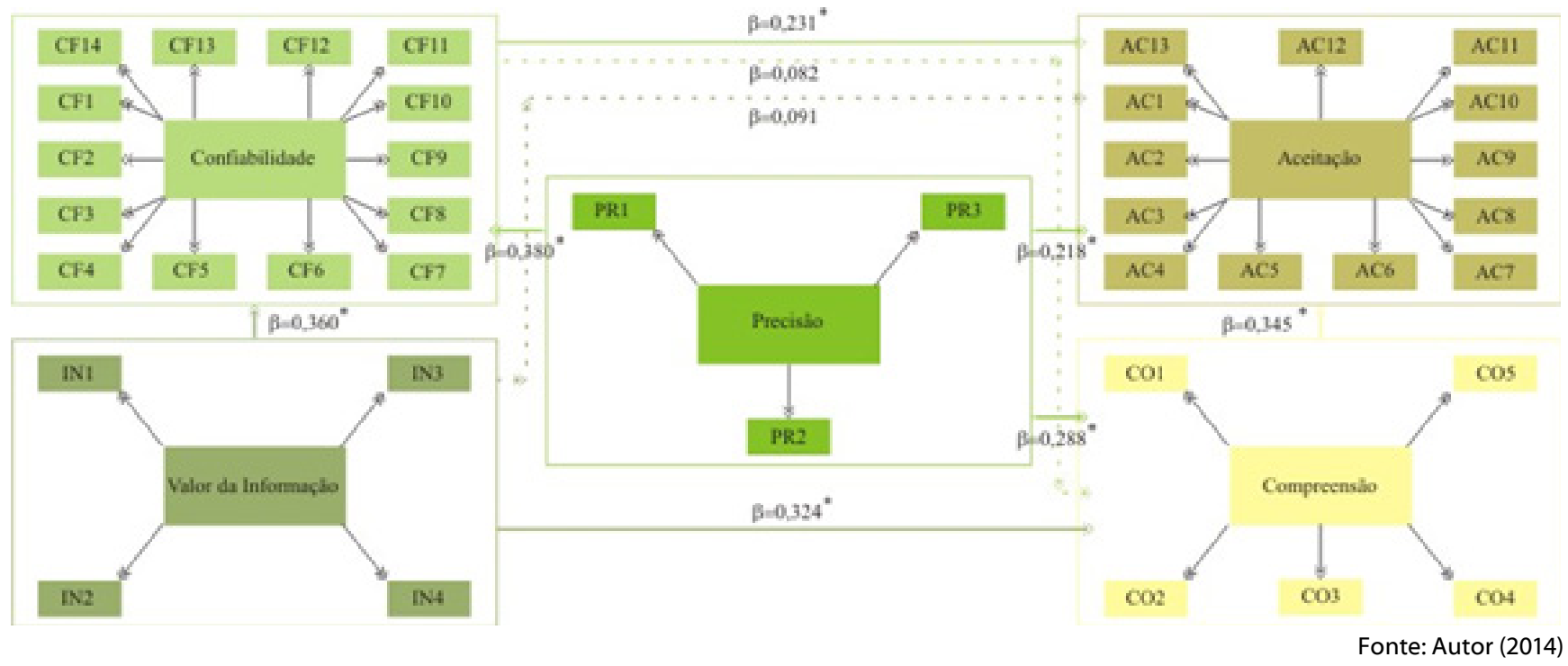

Figura 2: Representação do Modelo Estrutural 02 ajustado
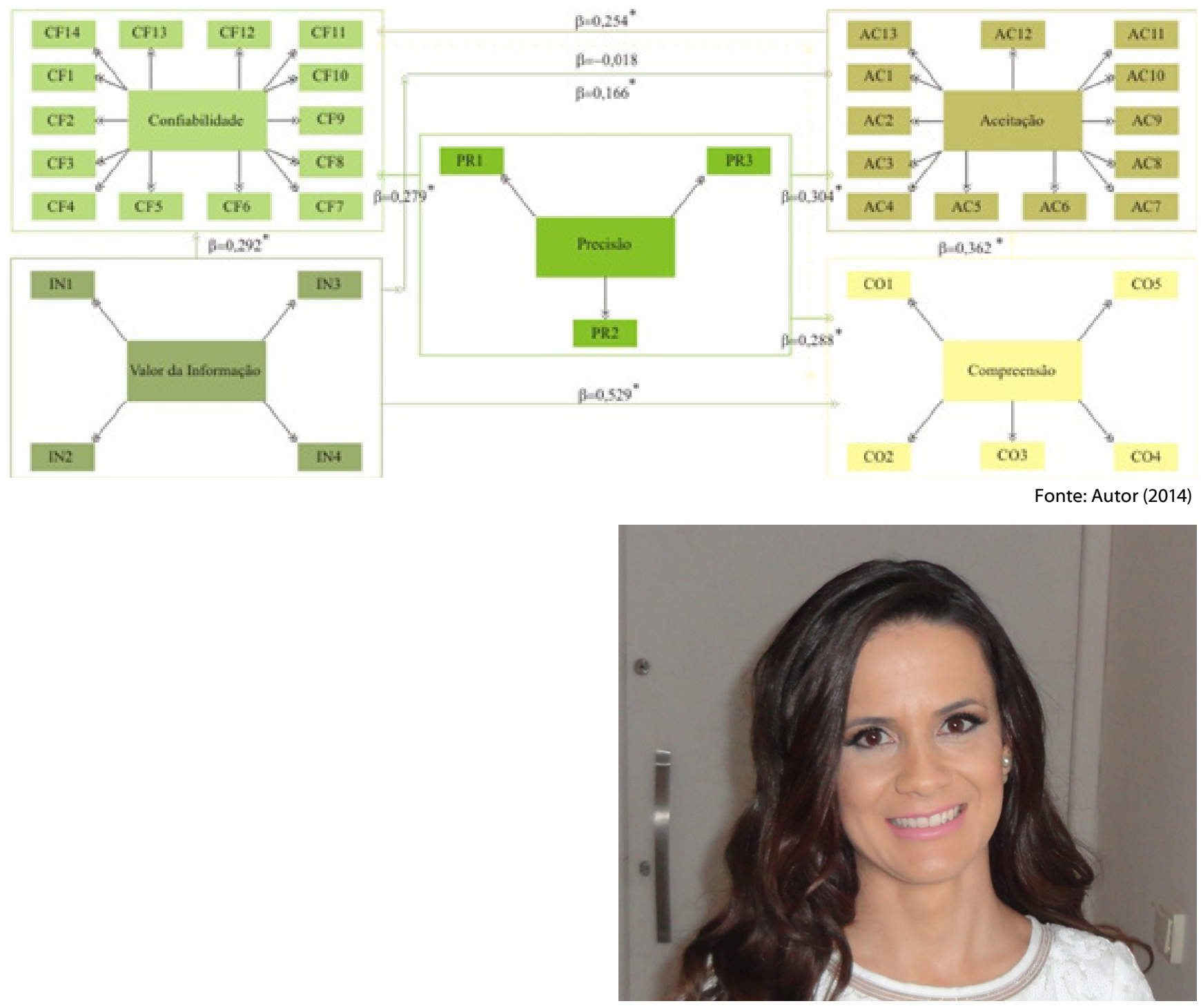